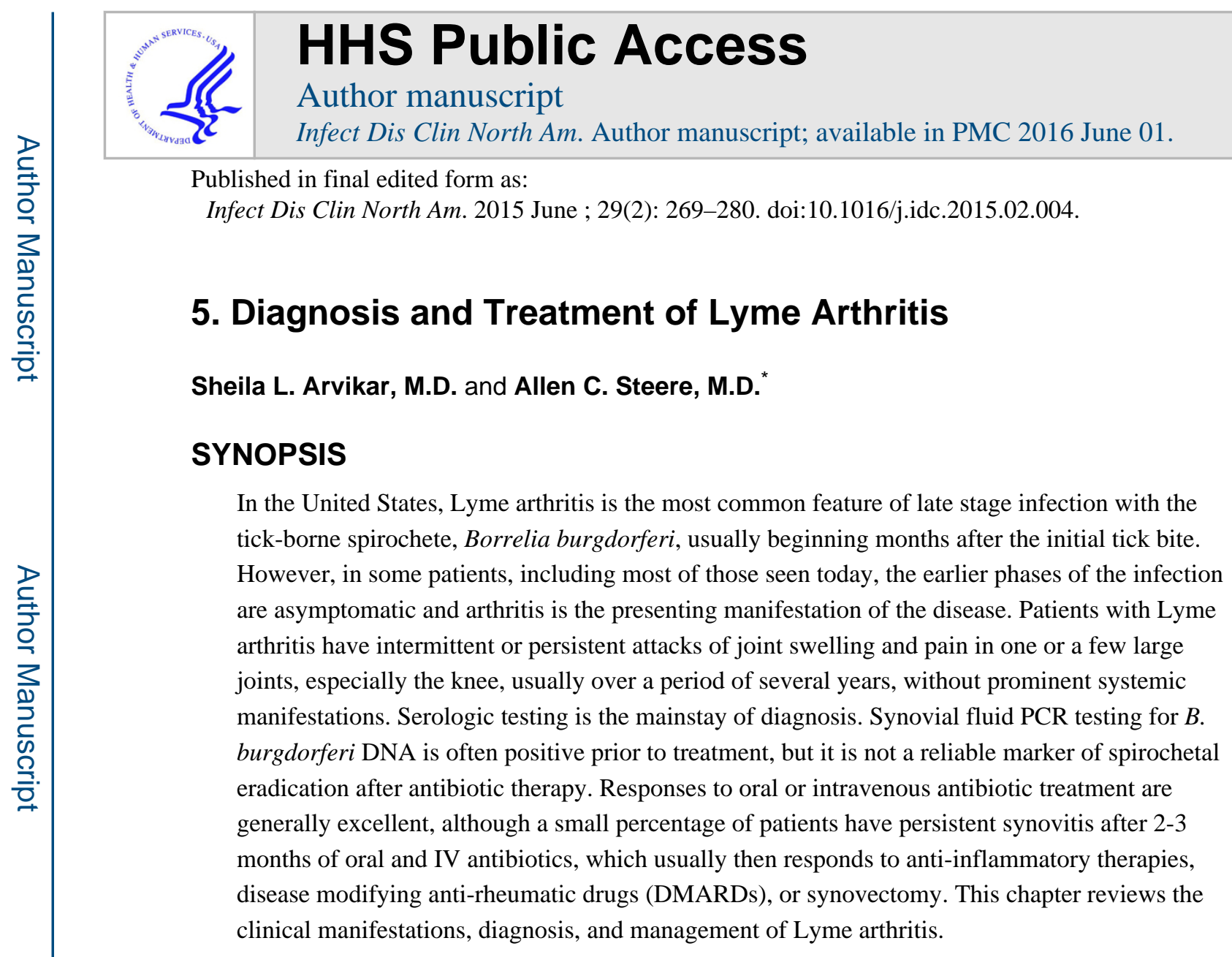

\title{
Keywords
}

Lyme disease; Borrelia burgdorferi; Lyme arthritis; Antibiotic-refractory arthritis; Inflammatory arthritis

\section{INTRODUCTION/NATURE OF THE PROBLEM}

\section{Epidemiology}

Lyme arthritis was originally recognized because of an outbreak of monoarticular and oligoarticular arthritis in children in Lyme, Connecticut in the 1970s. ${ }^{1}$ It then became apparent that Lyme disease was a complex multisystem illness affecting primarily skin, nervous system, heart or joints. ${ }^{2}$ Prior to the use of antibiotic therapy for treatment of the disease, about $60 \%$ of untreated patients developed Lyme arthritis, a late disease manifestation. ${ }^{3}$ In recent years, over 30,000 cases of Lyme disease have been reported annually to the Centers for Disease Control and Prevention (CDC), and in a third of reported

(C) 2015 Published by Elsevier Inc.

*corresponding author Center for Immunology and Inflammatory Diseases, Massachusetts General Hospital, Harvard Medical School, CNY149/8301, $14913^{\text {th }}$ Street, Charlestown, MA 02129. Phone: 617-726-1527. Fax: 617-726-1544. asteere@mgh.harvard.edu. sarvikar@mgh.harvard.edu

Publisher's Disclaimer: This is a PDF file of an unedited manuscript that has been accepted for publication. As a service to our customers we are providing this early version of the manuscript. The manuscript will undergo copyediting, typesetting, and review of the resulting proof before it is published in its final citable form. Please note that during the production process errors may be discovered which could affect the content, and all legal disclaimers that apply to the journal pertain. 
cases, arthritis was a manifestation of the disease. ${ }^{4}$ However, recent CDC estimates suggest the actual number of infections with the Lyme disease spirochete may be 10 -fold higher. ${ }^{5}$

The infection is transmitted primarily by nymphal Ixodes scapularis ticks, which quest in the late spring and early summer. ${ }^{6}$ However, Lyme arthritis can present at any time of the year. The majority of cases occur in the northeastern United States, from Maine to Virginia. ${ }^{5}$ Other affected areas in the U.S. include the northern mid-Western states of Minnesota, Wisconsin, and Michigan; and the West coast in northern California.

In the United States, Borrelia burgdorferi is the sole cause of the disease, but subtypes of $B$. burgdorferi differ in pathogenicity. ${ }^{7,8} \mathrm{OspC}$ type A (RST1) strains, which account for $30-50 \%$ of the infection in the northeastern US, ${ }^{7,8}$ but only $3 \%$ in mid-Western states, ${ }^{9}$ are particularly virulent and arthritogenic. These strains are thought to have played an important role in the emergence of the Lyme disease epidemic in the northeastern U.S. in the late $20^{\text {th }}$ century. ${ }^{10}$

\section{Pathogenesis}

In the northeastern USA, B. burgdorferi strains often disseminate to joints, tendons or bursae early in the infection. ${ }^{6}$ Although this event is frequently asymptomatic, transient or migratory arthralgias may occur at that time. Lyme arthritis, a late disease manifestation, usually occurs months later accompanied by intense innate and adaptive immune responses. ${ }^{11}$ The adaptive immune response leads to the production of specific antibodies, which opsonize the organism, facilitating phagocytosis and effective spirochetal killing

With appropriate oral and, if necessary, IV antibiotic therapy, spirochetes are eradicated, and joint inflammation resolves in the great majority of patients. However, in a small percentage of patients, particularly in those who were infected with highly inflammatory B. burgdorferi RST1 strains, synovial inflammation persists for months or several years despite receiving oral and intravenous antibiotic therapy for 2 or 3 months, called antibiotic-refractory arthritis. ${ }^{12}$ A refractory outcome is likely to require multiple factors, and may include some combination of pathogen-associated, genetic, and immunologic factors (Table 1).

Although antibiotic-refractory arthritis is associated with highly inflammatory strains of $B$. burgdorferi, persistent infection in the post-antibiotic-period does not appear to play role in this outcome. PCR testing of synovial fluid for B. burgdorferi DNA, which is often positive prior to treatment, is usually negative after antibiotic treatment, and both culture and PCR testing of synovial tissue have been uniformly negative from synovectomy specimens obtained months to years after antibiotic therapy. ${ }^{13}$

Rather, excessive inflammation during the infection, infection-induced autoimmunity, and failure to down-regulate inflammatory responses appropriately after spirochetal killing seem to be critical factors. Specifically, antibiotic-refractory arthritis is associated with specific HLADR alleles that bind an epitope of B. burgdorferi outer-surface protein A (OspA), leading to particularly strong Th1 responses. ${ }^{14}$ Additionally, this outcome occurs more often in patients with a TLR1 polymorphism (1805GG) that is found in half of the European Caucasian population, which leads to exceptionally high levels of cytokines and chemokines 
in affected joints. ${ }^{15}$ As evidence of immune dysregulation, patients with antibiotic-refractory arthritis have low frequencies of FoxP3+ regulatory T cells in synovial fluid; the lower the frequency, the longer the post-treatment duration of arthritis. ${ }^{16,17}$ In MyD88 -/- mice, spirochetal antigens are retained on cartilage surfaces, ${ }^{18,19}$ but it is not yet clear whether retained spirochetal antigens play a role in the post-antibiotic period in human Lyme arthritis. Finally, a novel human autoantigen, endothelial cell growth factor, was recently identified as a target of T- and B-cell responses in a subset of patients with Lyme disease, which provides the first direct evidence for autoimmune $\mathrm{T}$ - and B-cell responses in this illness. ${ }^{20}$ Additionally, synovial tissue in Lyme arthritis often shows obliterative microvascular lesions, and this finding correlates directly with the magnitude of ECGF antibody responses. ${ }^{21}$

Despite heightened immune reactivity, antibiotic-refractory arthritis eventually resolves. Thus, it seems that spirochetal killing, either by the immune system or with the assistance of antibiotic therapy, removes the innate immune "danger" signals. Without these signals, the adaptive immune response to autoantigens eventually regains homeostasis, and the arthritis resolves. This process may be facilitated by therapy with disease modifying anti-rheumatic drugs (DMARDs).

\section{PATIENT HISTORY}

During the 1970s before the cause of the disease was known, the natural history of Lyme arthritis was elucidated in a study of 55 non-antibiotic-treated patients who were followed prospectively from onset of erythema migrans (EM), the initial skin lesion, through the period of arthritis. ${ }^{3}$ Clinical features of the infection in these patients included the following:

- Arthritis began from 4 days to 2 years (mean, 6 months) after the EM skin lesion.

- Patients had intermittent or persistent attacks of joint swelling and pain, primarily in one or a few large joints, especially the knee, during a period of several years ${ }^{3}$ However, particularly in earlier episodes, other large or small joints, the temporomandibular joint, or periarticular sites (bursa, tendons) were sometimes affected.

- Generally fewer than 5 joints were affected at one time.

- Knee joints were often very swollen, but not particularly painful, and ruptured Baker's cysts were common.

- By the time arthritis was present, systemic manifestations (fever or other constitutional symptoms) were uncommon.

\section{Differential Diagnosis}

In addition to serologic testing, clinical features may distinguish Lyme arthritis from other arthritides. A common concern is mechanical injury in an active individual, and therefore, orthopedists are often the first specialist to see a patient with Lyme arthritis. However, the clinical picture of Lyme arthritis is most like reactive arthritis in adults or pauciarticular juvenile idiopathic arthritis in children, and serologic testing is essential to distinguish Lyme 
arthritis from these entities. Children may have a more acute presentation, with higher synovial WBC counts which may suggest a diagnosis of acute septic arthritis. ${ }^{22-24}$ However, Lyme arthritis typically causes only minimal pain with passive range of motion, and involvement of more than one joint (currently or by history) may help to distinguish Lyme arthritis from septic bacterial arthritis. ${ }^{22-24}$ Lyme arthritis rarely, if ever, causes chronic, symmetrical polyarthritis, which helps to distinguish Lyme arthritis from rheumatoid arthritis. Fibromyalgia is sometimes misdiagnosed as Lyme disease, but patients with fibromyalgia generally have diffuse pain, and they lack objective evidence of joint inflammation.

Other inflammatory arthritides, such as rheumatoid arthritis, reactive arthritis, or psoriatic arthritis may develop within months after Lyme disease, seemingly triggered by the spirochetal infection. Thus, these entities should be considered in the differential diagnosis. In endemic areas, concomitant positive serologic results for Lyme disease in patients with other inflammatory arthritides can present a diagnostic challenge, since antibody responses to $B$. burgdorferi following antibiotic-treated Lyme arthritis typically persist for many years. ${ }^{25}$

\section{PHYSICAL EXAMINATION}

Patients with Lyme arthritis typically have the following features on physical examination:

- Monoarthritis or oligoarthritis most commonly affecting the knees, but other large or small joints may be affected, such as an ankle, shoulder, elbow, or wrist.

- Affected knees may have very large effusions with warmth, but in contrast with typical bacterial (e.g., staphylococcal) septic arthritis, they are not particularly painful with range of motion or weight bearing. Baker's cysts may be present in the knees given the large size of effusions.

- Fever is usually not present.

A photograph of typical knee swelling in Lyme arthritis is shown in Figure 1.

\section{IMAGING AND ADDITIONAL TESTING}

\section{Serologic testing for Lyme disease}

The mainstay in diagnosing Lyme arthritis is serologic testing. In the USA, the CDC currently recommends a two-test approach in which samples are first tested for antibodies to B. burgdorferi by enzyme-linked immunosorbent assay (ELISA) and those with equivocal or positive results are subsequently tested by Western blotting (WB), with findings interpreted according to the CDC criteria. ${ }^{26}$ In contrast with early infection, when some patients may be seronegative, all patients with Lyme arthritis, a late disease manifestation, have positive serologic results for IgG antibodies to $B$. burgdorferi, with expansion of the response to many spirochetal proteins. ${ }^{27}$ When serum samples were tested with microarrays of more than 1200 spirochetal proteins, 120 proteins, primarily outer-membrane lipoproteins, were found to be immunogenic, and patients with Lyme arthritis had IgG 
reactivity to as many as 89 proteins. ${ }^{28}$ Serologic testing should be performed only in serum, as serologic tests in synovial fluid are not accurate. ${ }^{29}$

In addition to $\operatorname{IgG}$ antibody responses to $B$. burgdorferi, patients with Lyme arthritis may also have low-titer IgM reactivity with the spirochete. On the other hand, a positive IgM response alone in a patient with arthritis is likely to be a false-positive response or one indicative of previous, antibiotic-treated early Lyme disease in a patient who now has another type of arthritis. Therefore, positive IgM antibody responses alone should not be used to support the diagnosis of Lyme arthritis. After spirochetal killing with antibiotics, anti-spirochetal antibody titers decline gradually, but both the IgG and IgM responses in patients with past Lyme arthritis may remain positive for years, ${ }^{29}$ which seems to be an indicator of immune memory rather than active infection. We have not observed re-infection in patients with the expanded immune response generated in patients with Lyme arthritis. Therefore, a persistent, expanded IgG antibody response seems to be protective against reinfection, whereas the limited response seen in patients with erythema migrans is not.

\section{Synovial Fluid PCR for B. burgdorferi}

Although reported in a few patients, ${ }^{30}$ it is exceedingly difficult to culture B. burgdorferi from synovial fluid in patients with Lyme arthritis. This is presumably due to the fact that joint fluid, with its many inflammatory mediators, is an extremely hostile environment. In spiked cultures, adding small amounts of joint fluid results in rapid killing of spirochetes. ${ }^{13}$ In contrast, polymerase chain reaction (PCR) testing of synovial fluid for $B$. burgdorferi DNA often yields positive results before antibiotic therapy (range, 40-96\%), ${ }^{13,31}$ and usually becomes negative following antibiotic treatment. ${ }^{12}$ However, spirochetal DNA may persist after spirochetal killing, which limits its use as a test for active infection. Moreover, PCR testing has not been standardized for routine clinical use. Therefore, in most cases, the appropriate clinical picture and a positive serologic result are sufficient for diagnosis of Lyme arthritis, and PCR testing serves as an optional test to further support the diagnosis.

\section{Synovial Fluid Analysis, Imaging and Other Tests}

On presentation, joint aspiration is usually done for diagnostic purposes to rule out the presence of other arthritides such as crystalline arthropathy or staphylococcal septic arthritis. Joint fluid white cell counts are usually inflammatory in the range $(10,000$ to 25,000 cells $/ \mathrm{mm}^{3}$ ), but cell counts as low as 500 or as high as 100,000 cells $/ \mathrm{mm}^{3}$ have been reported. ${ }^{3}$ Although tests for rheumatoid factor or antinuclear antibodies typically yield negative results, antinuclear antibodies in low titer may be detected. Peripheral white blood cell (WBC) counts are usually within the normal range, but inflammatory markers, such as ESR and CRP, may be elevated. Imaging studies are not required for diagnosis or are not typically performed. The major reason for imaging studies in Lyme arthritis is when there are concerns for alternative diagnoses.

In patients with Lyme arthritis, plain films, MRI scanning or ultrasound typically show nonspecific joint effusions, while MRI studies utilizing contrast dye, may display synovial thickening or enhancement. In adult patients, imaging studies may show co-incidental degenerative changes or chronic mechanical injuries, but these abnormalities would not be 
expected to cause significant synovitis or inflammation. Lyme arthritis is not rapidly erosive, but with longer arthritis durations, joint damage can be seen on radiographic studies. ${ }^{32}$ Finally, MRI scanning may be useful in the planning of synovectomies by determining the extent of synovitis within the joint.

\section{Treatment}

Treatment of Lyme arthritis is based on several small, double-blind or randomized studies and observational studies (summarized in Table 2). The efficacy of antibiotics was first demonstrated in a double-blind, placebo-controlled trial of IM benzathine penicillin, 2.4 million units weekly for 3 weeks versus placebo. In that study, 7 of 20 antibiotic-treated patients (35\%) had complete resolution of arthritis, whereas all 20 placebo treatment patients continued to have arthritis. ${ }^{33}$ Subsequently, 11 of 20 patients (55\%) treated with IV penicillin, 20 million $\mathrm{U}$ daily in 6 divided doses for 10 days, had resolution of arthritis. ${ }^{33}$ It was then reported that IV ceftriaxone, $2 \mathrm{~g}$ daily, was effective in $90 \%$ of patients who were given 2-4 weeks of therapy. ${ }^{34}$ In a later randomized trial, treatment with 30 days of doxycycline, $100 \mathrm{mg}$ twice daily, or amoxicillin, $500 \mathrm{mg}$ four times daily, also led to resolution of arthritis in $90 \%$ of patients. ${ }^{35}$

According to current recommendations from the Infectious Diseases Society of America, ${ }^{36}$ patients with Lyme arthritis should be treated initially with a 30-day course of oral doxycycline, $100 \mathrm{mg}$ twice daily, or amoxicillin, $500 \mathrm{mg}$ three times daily. In patients who are unable to take either of these oral agents, cefuroxime axetil, $500 \mathrm{mg}$ twice daily, may be an acceptable alternative. This medication was shown to be equivalent to treatment with doxycycline or amoxicillin in patients with EM, ${ }^{37}$ but has not been studied systematically in patients with Lyme arthritis. Unless there are concomitant neurologic abnormalities, oral regimens are the initial treatment of choice as such therapy is safer and more cost effective.

In our experience, some patients do require longer courses of antibiotic therapy for effective treatment of Lyme arthritis. ${ }^{12}$ Thus, if there is mild residual joint swelling after a 30-day course of oral antibiotics, we repeat the oral antibiotic regimen for another 30 days.

However, for patients who continue to have moderate-to-severe joint swelling after a 30-day course of oral antibiotics, we treat with IV ceftriaxone, $2 \mathrm{gm} /$ day. Although there is trend toward greater efficacy with 4 weeks compared with 2 weeks of antibiotics, there is also a greater frequency of adverse events. ${ }^{38}$ Thus, our practice is to prescribe a 4-week course of IV therapy, but to monitor the patient closely and to stop the antibiotic if complications occur.

Even in patients who had minimal or no improvement with oral doxycycline, we typically observe moderate improvement or even complete resolution of arthritis with IV therapy. Moreover, even in those with persistent joint inflammation, the synovitis tends to change after IV therapy with decreased size of effusions but continued synovial tissue hypertrophy and inflammation. Courses of longer than 30 days of IV antibiotics seem not to be beneficial and may be associated with a still greater frequency of adverse effect. ${ }^{39}$ Additionally, a recent double-blind, randomized, placebo-controlled study of patients in Europe did not find a benefit of additional oral amoxicillin therapy following treatment with IV ceftriaxone. ${ }^{40} \mathrm{~A}$ number of newer oral antibiotics in an FDA approved drug library, including daptomycin, 
carbomycin, and cefoperazone, have been shown to have marked efficacy against persisting spirochetes in culture, ${ }^{41}$ but it is not yet known whether such antibiotics would be effective in patients with Lyme arthritis that is more difficult to treat.

\section{Adjunctive therapy}

During treatment, non-steroidal anti-inflammatory agents (NSAIDs), such as ibuprofen or naproxen, may be used for pain. We rarely give oral or intra-articular corticosteroids, and not until antibiotic treatment is completed, since these drugs permit greater growth of spirochetes, ${ }^{42}$ and because of the association of intra-articular steroid injections with a longer duration of arthritis in some studies. ${ }^{12,43}$ When joints are inflamed, reduction of activity is important. If patients are limping, we advise crutch walking. Children may be more likely to regain normal function within 4 weeks after the initiation of antibiotic treatment, ${ }^{23}$ but especially in adults, inflamed joints typically lead to quadriceps atrophy. Therefore, following the completion of antibiotic treatment and resolution of joint inflammation, formal physical therapy, including bicycle riding, is often needed.

\section{Therapy for Antibiotic-Refractory Arthritis}

The algorithm that we use for the diagnosis and treatment of antibiotic-refractory arthritis is shown in Figure 2. ${ }^{12}$ If synovitis persists following two or more months of oral antibiotics and one month of IV antibiotics, we employ a similar approach to that used in the treatment of other forms of chronic inflammatory arthritis, including rheumatoid arthritis and reactive arthritis. The agents used include NSAIDs, such as ibuprofen or naproxen, and DMARDs, such as hydroxychloroquine or methotrexate, depending on the severity of arthritis.

Although there have been no formal trials with these agents, in practice, they reduce severity of inflammation and have not resulted in break-through cases of active infection. We generally do not give oral or intra-articular injections of corticosteroids, even in the postantibiotic period, although others have reported clinical utility, particularly in the pediatric popultion. ${ }^{44,45}$

In more recent years, with greater experience using more potent DMARD agents, we have developed an enhanced treatment strategy, now more commonly choosing low-dose methotrexate (MTX), typically $15-20 \mathrm{mg} /$ week, over hydroxychloroquine as the initial DMARD, and reserving hydroxychloroquine, typically 400mg daily, for cases with milder synovitis. Moreover, in a few patients who had incomplete responses to MTX or in those with contraindications to MTX, we have used TNF inhibitors, generally injectable forms such as entanercept or adalimumab. ${ }^{12}$ The onset of action of MTX and other DMARDs can be slow, but we expect to see a significant response in 1-3 months. Since antibioticrefractory arthritis has resolved after a median duration of 9-to-14 months (range, 4 months to 4 years) after the start of antibiotic therapy, ${ }^{12}$ long courses of DMARD therapy are generally not needed. We typically prescribe these medications for only 6-12 months rather than indefinitely as in the treatment of patients with rheumatoid arthritis. If the response to a DMARD agent is incomplete and if the arthritis is limited to one joint, primarily the knee, arthroscopic synovectomy is an option. ${ }^{46}$ By removing most of the inflamed synovial tissue in both the anterior and posterior compartments of the knee, the arthritis does not usually recur when synovial tissue grows back. 


\section{SUMMARY}

Arthritis is a late manifestation of Lyme disease, usually beginning months after the tick bite. However, a history of erythema migrans or tick bite may be lacking. Patients have intermittent or persistent attacks of joint swelling and pain, primarily in one or a few large joints, often the knee, during a period of months to several years, with few systemic manifestations. The diagnosis is established by two-tier serologic testing for B. burgdorferi by ELISA and IgG Western blotting, which typically shows strong responses to many spirochetal proteins with many bands present. PCR testing of synovial fluid for $B$. burgdorferi DNA is often positive prior to antibiotic therapy, but the test is not a reliable indicator of spirochetal eradication following antibiotic treatment, since spirochetal DNA may persist after spirochetal killing. Initial recommended therapies include a 30-day course of oral doxycycline or amoxicillin. However, for patients with persistent joint swelling despite oral therapy, IV ceftriaxone for 2 to 4 weeks may be needed for successful treatment. A small percentage of patients may have persistent arthritis for months or several years after both oral and IV antibiotic therapy, which may be treated successfully with antiinflammatory agents, DMARDs, or synovectomy. The antibody response to B. burgdorferi declines slowly after treatment, but the test typically remains positive for years after therapy.

\section{REFERENCES}

1. Steere AC, Malawista SE, Snydman DR, et al. Lyme arthritis: an epidemic of oligoarticular arthritis in children and adults in three Connecticut communities. Arthritis Rheum. 1977; 20(1):7-17. [PubMed: 836338]

2. Steere AC, Malawista SE, Hardin JA, et al. Erythema chronicum migrans and Lyme arthritis. The enlarging clinical spectrum. Ann Intern Med. 1977; 86(6):685-98. [PubMed: 869348]

3. Steere AC, Schoen RT, Taylor E. The clinical evolution of Lyme arthritis. Ann Intern Med. 1987; 107(5):725-31. *Key article, doi:10.7326/0003-4819-107-5-725. [PubMed: 3662285]

4. Bacon RM, Kugeler KJ, Mead PS, Centers for Disease Control and Prevention (CDC). Surveillance for Lyme disease--United States, 1992-2006. MMWR Surveill Summ. 2008; 57(10):1-9. [PubMed: 18830214]

5. CDC estimates of Americans diagnosed with Lyme disease each year. Press release from the Centers for Disease Control and Prevention. Aug 13. 2013 (http://www.cdc.gov/media/releases/ 2013/p0819-lyme-disease.html)

6. Steere AC. Lyme disease. N Engl J Med. 1989; 321(9):586-96. *Key article, doi: 10.1056/ NEJM198908313210906. [PubMed: 2668764]

7. Wormser GP, Brisson D, Liveris D, et al. Borrelia burgdorferi genotype predicts the capacity for hematogenous dissemination during early Lyme disease. J Infect Dis. 2008; 198(9):1358-64. [PubMed: 18781866]

8. Jones KL, McHugh GA, Glickstein LJ. Analysis of Borrelia burgdorferi genotypes in patients with Lyme arthritis: High frequency of ribosomal RNA intergenic spacer type 1 strains in antibioticrefractory arthritis. Arthritis Rheum. 2009; 60(7):2174-82. el al. [PubMed: 19565522]

9. Hanincova K, Mukherjee P, Ogden NH, et al. Multilocus sequence typing of Borrelia burgdorferi suggests existence of lineages with differential pathogenic properties in humans. PLoS One. 2013; 8(9):e73066. [PubMed: 24069170]

10. Hoen AG, Margos G, Bent SJ, et al. Phylogeography of Borrelia burgdorferi in the eastern United States reflects multiple independent Lyme disease emergence events. Proc Natl Acad Sci U S A. 2009; 106(35):15013-8. [PubMed: 19706476]

11. Steere AC, Coburn J, Glickstein L. The emergence of Lyme disease. J Clin Invest. 2004; 113(8): 1093-101. [PubMed: 15085185] 
12. Steere AC, Angelis SM. Therapy for Lyme arthritis: strategies for the treatment of antibioticrefractory arthritis. Arthritis Rheum. 2006; 54(10):3079-86. *Key article, doi: 10.1002/art.22131. [PubMed: 17009226]

13. Li X, McHugh G, Damle N, et al. Burden and viability of Borrelia burgdorferi in skin or joints of patients with erythema migrans or Lyme arthritis. Arthritis Rheum. 2011; 63(8):2238-47. [PubMed: 21590753]

14. Steere AC, Drouin EE, Glickstein LJ. Relationship between immunity to Borrelia burgdorferi outer-surface protein A (OspA) and Lyme arthritis. Clin Infect Dis. 2011; 52(S3):S259-S265. [PubMed: 21217173]

15. Strle K, Shin JJ, Glickstein LJ, et al. Association of a toll-like receptor 1 polymorphism with heightened Th1 inflammatory responses and antibiotic-refractory Lyme arthritis. Arthritis Rheum. 2012; 64(5):1497-507. [PubMed: 22246581]

16. Shen S, Shin JJ, Strle K, et al. Treg cell numbers and function in patients with antibiotic-refractory or antibiotic-responsive Lyme arthritis. Arthritis Rheum. 2010; 62(7):2127-37. [PubMed: 20506317]

17. Vudattu NK, Strle K, Steere AC, et al. Dysregulation of CD4+CD25(high) T cells in the synovial fluid of patients with antibiotic-refractory Lyme arthritis. Arthritis Rheum. 2013; 65(6):1643-53. [PubMed: 23450683]

18. Bockenstedt LK, Gonzalez DG, Haberman AM, et al. Spirochete antigens persist near cartilage after murine Lyme borreliosis therapy. J Clin Invest. 2012; 122(7):2652-60. [PubMed: 22728937]

19. Wormser GP, Nadelman RB, Schwartz I. The amber theory of Lyme arthritis: initial description and clinical implications. Clin Rheumatol. 2012; 31(6):989-94. [PubMed: 22411576]

20. Drouin EE, Seward RJ, Strle K, et al. A novel human autoantigen, endothelial cell growth factor, is a target of T and B cell responses in patients with Lyme disease. Arthritis Rheum. 2013; 65(1): 186-96. [PubMed: 23044924]

21. Londoño D, Cadavid D, Drouin EE, et al. Antibodies to endothelial cell growth factor and obliterative microvascular lesions in the synovium of patients with antibiotic-refractory Lyme arthritis. Arthritis Rheumatol. 2014; 66(8):2124-33. [PubMed: 24623727]

22. Aiyer A, Hennrikus W, Walrath J, et al. Lyme arthritis of the pediatric lower extremity in the setting of polyarticular disease. J Child Orthop. Jul 23.2014 [Epub ahead of print].

23. Daikh BE, Emerson FE, Smith RP, et al. Lyme arthritis: a comparison of presentation, synovial fluid analysis, and treatment course in children and adults. Arthritis Care Res. 2013; 65(12):198690.

24. Deanehan JK, Kimia AA, Tan Tanny SP, et al. Distinguishing Lyme from septic knee monoarthritis in Lyme disease-endemic areas. Arthritis Rheumatol. 2014; 66(8):2124-33. [PubMed: 24623727]

25. Kalish RA, McHugh G, Granquist J, et al. Persistence of immunoglobulin M or immunoglobulin G antibody responses to Borrelia burgdorferi 10-20 years after active Lyme disease. Clin Infect Di. $2001 ; 33(6): 780-5$.

26. Centers for Disease Control and Prevention. Recommendations for test performance and interpretation from the Second International Conference on serologic diagnosis of Lyme disease. MMWR Morb Mortal Wkly Rep. 1995; 44(31):590-1. [PubMed: 7623762]

27. Steere AC, McHugh G, Damle N, et al. Prospective study of serologic tests for Lyme disease. Clin Infect Dis. 2008; 47(2):188-95. [PubMed: 18532885]

28. Barbour AG, Jasinskas A, Kayala MK, et al. A genome-wide proteome array reveals a limited set of immunogens in natural infections of humans and white-footed mice with Borrelia burgdorferi. Infect Immun. 2008; 76(8):3374-89. [PubMed: 18474646]

29. Barclay SS, Melia MT, Auwaerter PG. Misdiagnosis of late-onset Lyme arthritis by inappropriate use of Borrelia burgdorferi immunoblot testing with synovial fluid. Clin Vaccine Immunol. 2012; 19(11):1806-9. [PubMed: 22971779]

30. Snydman DR, Schenkein DP, Berardi VP, et al. Borrelia burgdorferi in joint fluid in chronic Lyme arthritis. Ann Intern Med. 1986; 104(6):798. [PubMed: 3518562] 
31. Nocton JJ, Dressler F, Rutledge BJ, et al. Detection of Borrelia burgdorferi DNA by polymerase chain reaction in synovial fluid in Lyme arthritis. N Engl J Med. 1994; 330(4):229-34. [PubMed: 8272083]

32. Lawson JP, Steere AC. Lyme arthritis: radiologic findings. Radiology. 1985; 154(1):37-43. [PubMed: 3964949]

33. Steere AC, Green J, Schoen RT, et al. Successful parenteral penicillin therapy of established Lyme arthritis. N Engl J Med. 1985; 312(14):869. [PubMed: 3883177]

34. Dattwyler RJ, Halperin JJ, Volkman DJ, et al. Treatment of late Lyme borreliosis--randomised comparison of ceftriaxone and penicillin. Lancet. 1988; 1(1896):1191-4. [PubMed: 2897008]

35. Steere AC, Levin RE, Molloy PJ, et al. Treatment of Lyme arthritis. Arthritis Rheum. 1994; 37(6): 878-88. [PubMed: 8003060]

36. Wormser GP, Dattwyler RJ, Shapiro ED, et al. The clinical assessment, treatment, and prevention of lyme disease, human granulocytic anaplasmosis, and babesiosis: clinical practice guidelines by the Infectious Diseases Society of America. Clin Infect Dis. 2006; 43(9):1089-34. *Key article, doi: 10.1086/508667. [PubMed: 17029130]

37. Nadelman RB, Luger SW, Frank E, et al. Comparison of cefuroxime axetil and doxycycline in the treatment of early Lyme disease. Ann Intern Med. 1992; 117(4):273-80. [PubMed: 1637021]

38. Dattwyler RJ, Wormser GP, Rush TJ, et al. A comparison of two treatment regimens of ceftriaxone in late Lyme disease. Wien Klin Wochenschr. 2005; 117(11-12):393-7. [PubMed: 16053194]

39. Fallon BA, Keilp JG, Corbera KM, et al. A randomized, placebo-controlled trial of repeated IV antibiotic therapy for Lyme encephalopathy. Neurology. 2008; 70(13):992-1003. [PubMed: 17928580]

40. Oksi J, Nikoskelainen J, Hiekkanen H, et al. Duration of antibiotic treatment in disseminated Lyme borreliosis: a double-blind, randomized, placebo-controlled, multicenter clinical study. Eur J Clin Microbiol Infect Dis. 2007; 26(8):571-81. [PubMed: 17587070]

41. Feng J, Wang T, Shi W, et al. Identification of novel activity against Borrelia burgdorferi persisters using an FDA approved drug library. Emerging Microbes \& Infections. 2014; 3:e49.

42. Pachner AR, Delaney E, O’Neill T. Neuroborreliosis in the nonhuman primate: Borrelia burgdorferi persists in the central nervous system. Ann Neurol. 1995; 38(4):667-9. [PubMed: 7574465]

43. Bentas W, Karch H, Huppertz HI. Lyme arthritis in children and adolescents: outcome 12 months after initiation of antibiotic therapy. J Rheumatol. 2000; 27(8):2025-30. [PubMed: 10955347]

44. Nimmrich S, Becker I, Horneff G. Intraarticular corticosteroids in refractory childhood Lyme arthritis. Rheumatol Int. 2014; 34(7):987-94. [PubMed: 24390634]

45. Tory HO, Zurakowski D, Sundel RP. Outcomes of children treated for Lyme arthritis: results of a large pediatric cohort. J Rheumatol. 2011; 37(5):1049-55. [PubMed: 20360182]

46. Schoen RT, Aversa JM, Rahn DW, et al. Treatment of refractory chronic Lyme arthritis with arthroscopic synovectomy. Arthritis Rheum. 1991; 34(8):1056-60. [PubMed: 1859481] 


\section{KEY POINTS}

- Lyme arthritis is a late disease manifestation, usually beginning months after the tick bite. Patients may not report an antecedent tick bite or erythema migrans (EM).

- Patients have intermittent or persistent attacks of joint swelling and pain, in one or a few large joints, especially the knee, without prominent systemic manifestations.

- The diagnosis is supported by 2-tier serologic testing for B. burgdorferi by ELISA and IgG Western blotting.

- Initial treatment is a 30-day course of oral doxycycline or amoxicillin. For patients with an insufficient response to oral treatment, IV therapy with ceftriaxone is recommended.

- A minority of patients may have persistent synovitis for months or several years after oral and IV antibiotic therapy, which is treated with anti-inflammatory agents, DMARDs, or synovectomy. 


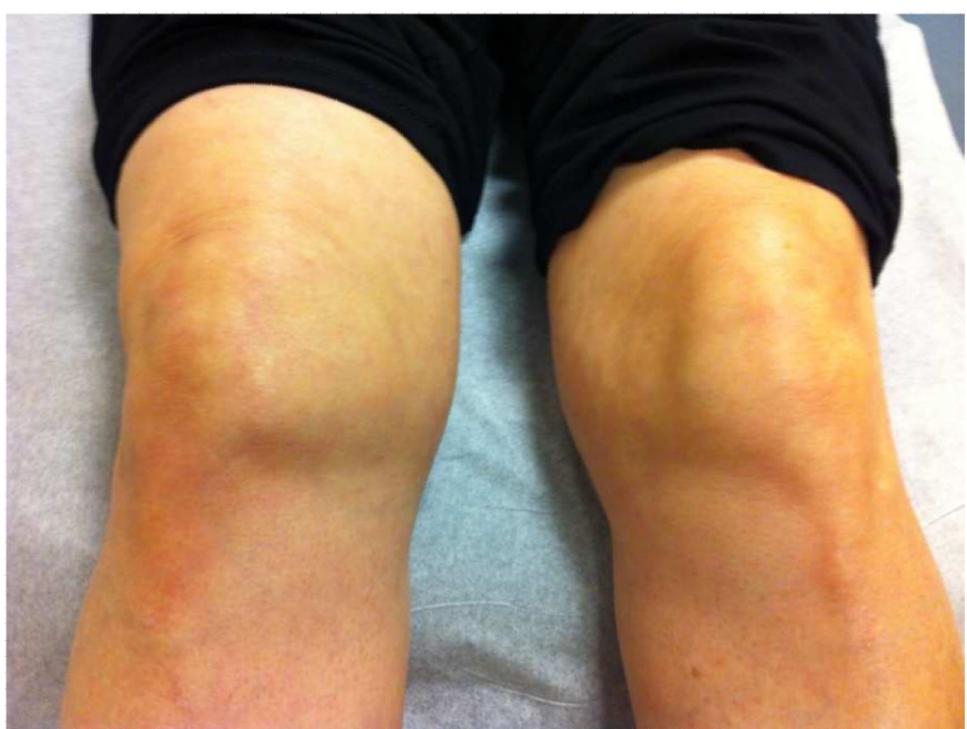

Figure 1.

Lyme arthritis. A swollen knee of a patient with Lyme arthritis is shown. Patients have intermittent or persistent attacks of joint swelling and pain, primarily in one or a few large joints, especially the knee, during a period of several years, with few systemic manifestations. 


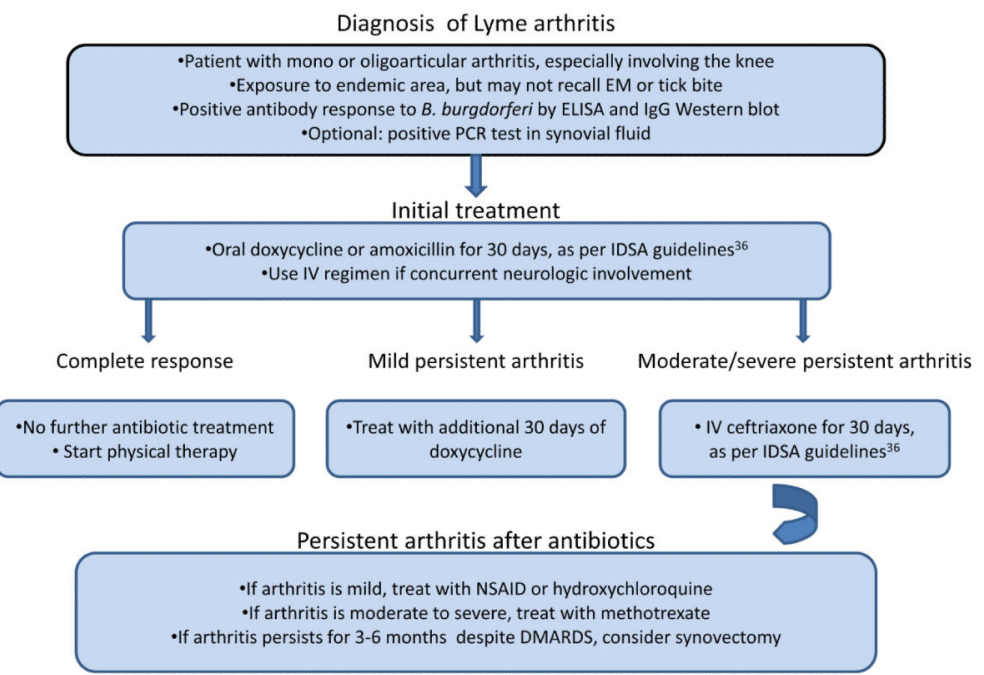

Figure 2.

Algorithm for the diagnosis and treatment of Lyme arthritis. EM = erythema migrans; ELISA = enzyme-linked immunosorbant assay; $\mathrm{PCR}=$ polymerase chain reaction; IDSA = Infectious Disease Society of America; IV= intravenous; NSAID = nonsteroidal antinflammatory drug; DMARDs = disease modifying anti-rheumatic drugs 


\section{Table 1}

Factors Associated with Antibiotic-refractory Lyme arthritis

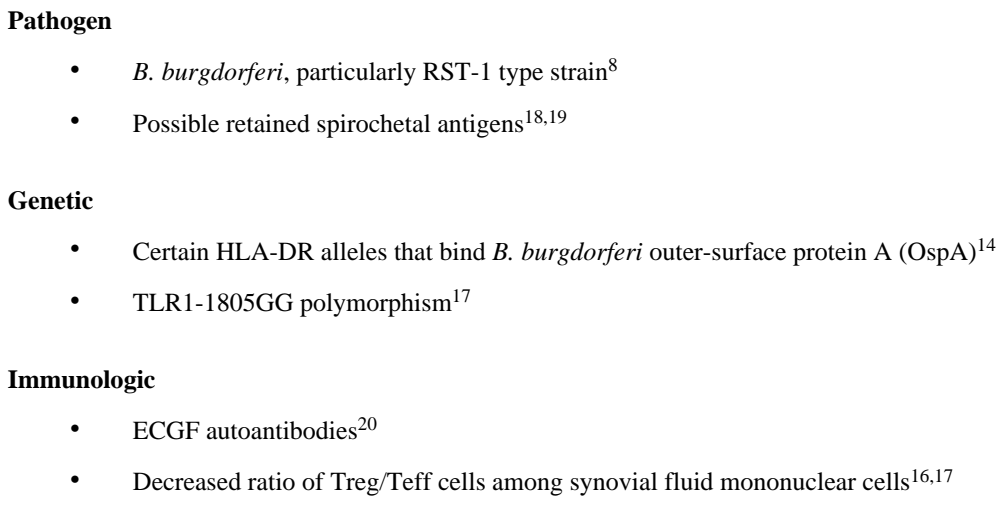


Table 2

Prospective Studies of Antibiotic Therapy in Lyme arthritis

\begin{tabular}{|c|c|c|c|c|}
\hline Author & Year & Trial type/Treatment & Patients & Outcomes \\
\hline Steere et al. ${ }^{32}$ & 1985 & $\begin{array}{l}\text { Double-blind, placebo-controlled } \\
\text { trial of intramuscular benzathine } \\
\text { penicillin (PCN) for } 3 \text { weeks vs. } \\
\text { placebo } \\
\text { Additional } 20 \text { patients received IV } \\
\text { PCN } 20 \text { million units/day for } 10 \\
\text { days }\end{array}$ & $\begin{array}{l}40 \text { with Lyme arthritis } \\
20 \text { with Lyme arthritis }\end{array}$ & $\begin{array}{l}7 / 20(35 \%) \mathrm{PCN} \\
\text { treated patients had } \\
\text { complete response } \\
\text { versus } 0 / 20 \text { in placebo } \\
\text { arm }(\mathrm{P}=0.02) \\
11 / 20(55 \%) \text { had } \\
\text { complete resolution }\end{array}$ \\
\hline Dattwyler et al. ${ }^{33}$ & 1988 & $\begin{array}{l}\text { Randomized to IV treatment with } \\
\text { PCN (10 days) or ceftriaxone } \\
\text { (CTX) (14 days) } \\
\text { Additional non-randomized cohort } \\
\text { treated with CTX } 2 \text { or } 4 \mathrm{~g}\end{array}$ & $\begin{array}{l}23 \text { patients with late } \\
\text { Lyme (16 with } \\
\text { arthritis) } \\
31 \text { patients ( } 23 \text { with } \\
\text { arthritis) }\end{array}$ & $\begin{array}{l}5 / 10 \text { responded to } \\
\text { PCN versus } 12 / 13 \\
\text { responded to CTX } \\
27 / 31 \text { patients } \\
\text { responded to CTX } \\
\text { Overall }>90 \% \\
\text { response to CTX }\end{array}$ \\
\hline Steere et al. ${ }^{34}$ & 1994 & $\begin{array}{l}\text { Randomized trial of doxycycline } \\
\text { or amoxicillin plus probenecid for } \\
30 \text { days, } \\
\text { Or } \\
2 \text { weeks of IV CTX for patients } \\
\text { with persistent arthritis } 3 \text { mos after } \\
\text { oral antibiotics or PCN }\end{array}$ & 50 with Lyme arthritis & $\begin{array}{l}18 / 20 \text { patients } \\
\text { receiving doxycycline } \\
\text { and } 16 / 18 \text { receiving } \\
\text { amoxicillin had } \\
\text { complete response by } \\
3 \text { months. } 5 \text { patients } \\
\text { later developed } \\
\text { neuroborreliosis. } \\
0 / 16 \text { patients treated } \\
\text { with IV CTX had } \\
\text { resolution with } 3 \text { mos. }\end{array}$ \\
\hline Dattwyler et al. 37 & 2005 & $\begin{array}{l}\text { Randomized trial of CTX, } 14 \text { vs. } \\
28 \text { day regimen }\end{array}$ & $\begin{array}{l}143 \text { patients with late } \\
\text { Lyme disease }\end{array}$ & $\begin{array}{l}5 \text { failures out of } 80 \\
\text { patients in } 14 \text {-day } \\
\text { group, but } 0 \text { failures } \\
\text { out of 63patients in } \\
\text { 28-day group } \\
(\mathrm{P}=0.07) \text {. } \\
\text { Increased adverse } \\
\text { events in } 28 \text {-day } \\
\text { group }(\mathrm{P}=0.02)\end{array}$ \\
\hline Oksi et al. ${ }^{39}$ & 2007 & $\begin{array}{l}\text { Double-blind randomized placebo } \\
\text { controlled trial of adjunct oral } \\
\text { antibiotic therapy (amoxicillin) vs. } \\
\text { placebo for } 100 \text { days following } 3 \\
\text { weeks of IV CTX }\end{array}$ & $\begin{array}{l}107 \text { patients with } \\
\text { definite disseminated } \\
\text { Lyme disease, } \\
\text { including } 45 \text { with } \\
\text { arthritis }\end{array}$ & $\begin{array}{l}\text { Excellent/good } \\
\text { response in } 49 / 53 \text { in } \\
\text { amoxicllin group and } \\
47 / 54 \text { in placebo } \\
\text { treated groups (NS). } \\
37 / 45 \text { Lyme arthritis } \\
\text { patients had excellent } \\
\text { or good responses. }\end{array}$ \\
\hline
\end{tabular}

Abbreviations: Penicillin (PCN), intravenous (IV), ceftriaxone (CTX) 